\title{
Analysis on Preparation and Implementation of Students' Presentations as a Learning Process in Class
}

\author{
Daroe Iswatiningsih \\ University of Muhammadiyah Malang \\ daroe@umm.ac.id
}

\begin{abstract}
The process of learning in university invites the students to be able to think rationally and systematically. In the field of social sciences and humanities, the students are required to be able to capture, explain, and interpret facts and phenomena that are found to be easier and simpler based on existing concepts and theories and able to develop into a new theoretical yield. Discussion learning method becomes a learning strategy in the college so that the students are able to argue over ideas and thoughts possessed. The presentation is the presentation of concepts, theories, and ideas based on a topic discussed in each group and in other groups. The preparation and implementation of the presentation are indicators of the competence of the presenter, both personal and group.
\end{abstract}

Keyword: preparation of the presentation, implementation of the presentation, learning process

\section{INTRODUCTION}

Universities, especially the Faculty of Teacher Training and Education (FTTE), try to make their graduates become teachers. As a teacher, of course, it is required to have an adequate and professional competence in their fields. Teachers, as professions, have three obligations to their students, which are to educate, teach, and train. As an educator, the teacher's job is to providea good example, continue to give good values and remind the learners when they do bad things. Asa teacher, they deliver knowledge; understand concepts and theories rationally so that the students understand and comprehend, not merely memorize concepts and facts. The teacher's third job is to train, that is, to develop skills required to be mastered by the students. This is in line with the Government Regulation No.19 of 2015 on National Education Standards, which formulates four types of competencies, namely pedagogic competence, personality competence, social competence, and professional competence [1].

During the learning process in college, the students of the Teacher Training and Education Faculty will get a number of courses that equip them to master the four competencies above. Some of the subjects presented are grouped into four sections, namely, the courses of spiritual development and personality, education courses, science courses, and skill courses. Therefore, at every stage or semester,the students always learn to develop themselves to master and understand the various knowledge and skills taught.

\section{METHOD}

The research employs descriptive qualitative, that is describing facts and phenomena of the students' activity during the learning process in the form of preparation and implementation of presentation in class. The researcher makes observation instruments during the student presentations. There are three classes studied. Each class consists of 36-45 students.

Each class member formed a group of four to discuss each topic. Group topics were chosen by drawing. Each topic is discussed by the two groups presented in the panel. It is intended that the material and the development of the topics presented can be broad and comprehensive.

Based on the observations and the researcher's notes on the student activities during the learning process, then, it is made identification, classification, and interpretation of the results of facts and phenomena during the preparation and implementation of the presentation.

\section{RESULT}

During the learning process using the discussion method with the paper presented as the product, the findings were obtained that included (1) preparation, as a group's thinking in the form of paper, and (2) implementation, namely the making of power point (PPT) to help direct the presentation and delivery of the main ideas in the paper.

\section{A. Papers Making as a Product of the Group's Thinking}

The paper that the group has made as a form of accountability for the results of a topic discussed is basically a collective work. The paper is a reflection of group competence, from the problem-content aspect, language, and other supporters of a scientific work. However, these last two aspects are under-scrutiny, namely the language aspect and the scientific aspects of the work.

From the content aspect, the students have been able to find different types of information that support the issues discussed. However, from the aspect of language, especially the use of spelling and the use of effective 
sentence, the students have less attention. Errors in spelling include (a) the use of punctuation, (b) the use of letters, and (c) word-writing. The writer's errors in using punctuation include: using (i) a period (.), the use of space at the end of a sentence, and (ii) comma punctuation (,) as the details are not followed by a space. Writing errors in the use of letters are visible on (i) writing scientific names and foreign phrases that are not written in italics and (ii) capital letter writing in geographical names and direct passages. The errors of word writing are often done by the students in preparing papers, namely (i) the use of the prefix "di-". They often misplace "di-" as a preposition in which the writing is separated and "di-" as a prefix whose writing is coupled with the following word.

Another aspect of language that the students do not pay attention to in preparing the papers in terms of writing is effective sentence. Effective sentence is a sentence which is easily understood by the readers. To the end, the main ideas and explanatory ideas in a sentence are clear. Typically, this effective expression is formulated not too long and shows the existence of a subject, predicate, and object or a clear description. The students' weakness to write the effective sentence is indicated by (i) the use of a hyphen at the beginning of a sentence, such as "and", "that is/ are", "for example", and "while", (ii) hanging or unfinished sentences, and (iii ) sentences that have two main ideas.

The weaknesses of the students' papers from the aspects of scientific work are seen in (a) systematic arrangement, (b) techniques in citing sources, and (c) writing bibliographies. Some of the student-made papers as a result of group discussions are not systematically arranged, ranging from (i) the formulation of backgrounds that addresses the issues and objectives of writing, (ii)the digital numbering that shows the details clearly, and (iii) the paper writing papers. The weaknesses in quoting the sources of information are illustrated in (i) not writing the entire quoted quotations, (ii) mentioning the names of the authorized sources of the author without the year and page, (iii) the name of the authorized sources the writer cited with the title, iv) and the nature of the citation which is taken directly from the reference source.

The third weakness in writing papers is on the aspects of scientific work, namely writing bibliographies. The students assume that listing the reference is the obligation of the lecturer when writing papers. The students are considered to have mastered the ability to write a bibliography. Therefore, most of the students in writing the bibliography have considered the name sequence alphabetically, but pay less attention to (i) consistency in writing more than one word of the author's names and (ii) the location of the content of the literature sources, (iii) tend to quote from the blog or specific pages, and (iv) there is less match between the sources written in the bibliography and the citation content.

\section{B. The Making of Presentation Media}

Moreover, if the information presented is arranged systematically in the form of ideas, it will be easy to read and understand. However, based on the researcher's observation, when the students make the PowerPoint media(PPT), there are still three weaknesses; it (i) tends to be in the form of full text (ii), and has too many slides and (iii) unattractive designs.

In the early stages of making the PowerPoint media, most of the groups present the information by copying the text on the paper. They cite parts of the paragraph deemed appropriate for the purpose of exposure. Taking materials from the papers only result in too many slides. Meanwhile, the time provided for each group is only fifteen minutes $\left(15^{\prime}\right)$. Therefore, when the moderator reminds the remaining time available to the presenters, the explanation becomes accelerated and even some parts are skipped.

The third weakness in making the power point is the unattractive design. Some things to note in PPT design making are the color that is too contrasting and makes the eyes tired. Also, the images displayed make the information less focused and vice versa without animation and pictures at all.

\section{The Implementation of Presentation}

A presentation is the author's responsibility to present the ideas outlined in the paper. Presentations may be represented by one group member who submits it. However, generally during the presentation, all group members participate in delivering their parts. From the presentation, it is revealed that there are four weaknesses that are often shown by the groups, namely: (1) conveying ideas, (2) grasping the intent or content of the questions, (3) answering the questions and (4) the lack of empathy among groups.

The first fact, when delivering the material, actually the group has been guided by the PowerPoint that has been prepared. However, in delivering the material, there are some weaknesses; the presenter (a) tends to read the text only, (b) lacks interaction with the participants, (c) lacks time management, and (d) lacks confidence.

During the presentation, the speaker tends to read the text in PPT. They do not tend to give an explanation of the written points of the ideas. This is in accordance with their way when writing the ideas in PPT which is full of text. Because only by reading the text alone, the speaker is unable to build interactions with the participants. Weak interactions built between the presenters and the participants are the evident from the lack of eye contact and the participants' presence in the discussions. The speaker only faces the screen to read out the texts listed there without a moment's notice and communication with the participants. Finally, some weaknesses experienced by the students in presenting ideas ideally are due to lack of confidence. Confidence is one's ability to trust oneself [4]. A person who has selfconfidence will be able to do anything in accordance with the ability that is owned. 
One's confidence can be grown and developed from inside and outside. Ssuggests there are five aspects that affect one's self-confidence, namely (1) belief in selfability, a person's positive attitude about himself; (2) optimism, a positive attitude of a person who always has a good view in facing all things; (3) objectiveness, the attitude of a person who sees everything in accordance with the proper truth; (4) responsibility, one's willingness to bear everything that has become its consequence; and (5) rationality and reality, the abilities to analyze problems or events by using a reasonable mind.

The students' lack of confidence in communicating during the presentation will have an effect on low selfesteem. Thus, the students are unable to build interpersonal relationships. The students, who have confidence, generally have the courage, ability, and capability to initiate, interact, and communicate. A person's self-confidence can be built and trained in a person especially from the social environment [2].

The second fact, after the material delivery by the group, then the next session is question-answer and feedback from the participants. In this session, it can be seen the students' weakness in capturing the participants' intent or content of the questions. The speaker's weakness is seen from his attitude that (a) does not note down questions, (b) try to answer but not in accordance with the participants' intentions, and (c) ask the questions again to the questioner or moderator.

When the participants ask the question, usually the group member hands over the task of noting to the moderator or the group leader. By noting the main points of the questions, the students will indirectly think and try to find the answer. On the contrary, if the students do not try to recognize the questions that the participants ask, their minds will be closed to solve the problem. Such students generally rely on the ability of others and do not try to be active in the discussion. [3] showed a linear relationship in confident students between their achievement and self-confidence.

The third fact is, as the group members do not attempt to note the questions, so when the moderator asks the group to answer, they are confused. Generally, the moderator will re-read the participants' questions. The group members who do not note the questions are generally not ready with the answers. They give an initial chance to answer the group leader.

There are also group members who try to answer the question but the results are not in accordance with the intent of the questioner. In reality, there are students who have difficulties in communicating with others (interpersonal communication), both in the process of learning in class and in an informal atmosphere outside the classroom. One of the most likely causes of interpersonal communication difficulties is anxiety.

The students' anxiety arises from the fear of receiving a negative response or judgment from the communicant or the person receiving the message. In response to this condition, [4] stated that if a person is difficult to communicate his ideas to others. Then, he can be categorized as an inferior person. For that reason, some of students' weaknesses during the presentation, especially in question-answer session, can be summarized below (i) the group takes a long time to discuss thinking about the answer, (ii) tends to give short answers without any reasons and examples, (iii) group members tend not to add and complete the answers of their friends because one team answer is considered to be quite representative for the other members, (vi) the students tend to seek answers on mobile phones; (vii) not all group members carry the paper which has been prepared, and (viii) the mastery of the content is still weak.

The fourth fact, there is lack of empathy among groups during the presentation. This condition is indicated during a panel presentation - because the topics are the same, each group (a) does not pay attention to other groups during presentation, (b) lacks attention to other groups when answering the participants' questions, and (c) does not try to help other groups when having a difficulty answering participants' questions.

[5] argues that empathy is a person's ability to understand the feelings and emotions of others and the ability to imagine oneself in other people's place. Someone who empathizes with others will try to help them wholeheartedly. In Myers' view,[6] empathy is the desire to help others without thinking of self-interest. The empathy among groups in the learning process is the attitude of mutual understanding of the difficulties felt by other groups. If this attitude is maintained, then there will be an attitude of intergroup cooperation. This form builds an inter-group empathetic attitude during the presentation by (i) being silent and taking into account of other groups, (ii) following other groups' explanations when answering questions, and (iii) helping to answer the participants' questions that other groups find difficult. If some of these weaknesses can be overcome well, then the learning process with the method of discussion and presentation will run dynamically.

\section{CONCLUSION}

As a prospective teacher, the students of the Teacher Training and Education Faculty must have the ability to communicate well. The form of communication is interpersonal, between individuals, both individuals, and groups. By communicating, the communicators know each other and learn both themselves and the outside world. Also, the methods of discussion and presentation in learning enable students to try to equate ideas, thoughts, and attitudes, until the message is obtained by both parties who hold the discussion. Some students' weaknesses in the presentation need to be improved and addressed. Therefore, the application of discussion and presentation methods in learning needs to be accompanied and evaluated until the students are no longer feel anxious, fearful, and have low self-esteem. Building the students' self-confidence, both internally and externally, is important especially in creating a conducive classroom atmosphere. 


\section{REFERENCES}

[1] Hurlock, EB. Perkembangan anak. Jilid2. Alih Bahasa: Med. Meitasari Tjandrasa dan MuslichahZarkasih.Edisi keenam. Jakarta: Erlangga. 1999.

[2] Kusrini, Woro dan Prihartanti, Nanik. Hubungan Dukungan Sosial dan Kepercayaan Diri dengan Prestasi Bahasa Inggris Siswa Kelas VIII SMP Negeri 6 Boyolali. Jurnal Penelitian Humaniora, Vol.15, No.2, Agustus 2014:131-140. 2014.
[3] Lauster. The Personality Test. London: Pan Books. 2002.

[4] Perry, Martin. Confidence Boosters Pendongkrak Kepercayaan Diri. Jakarta: Esensi. 2005.

[5] Rakhmat, J..Psikologi Komunikasi. Bandung: Remaja Karya. 1986.

[6] Sarwono, S.W. Psikologi sosial, Individu danTteori-teori Psikologi Sosial . Jakarta: Balai Pustaka. 2002. 